\title{
STUDY OF THE SUSTAINED SPEED OF KILL OF THE COMBINATION OF FIPRONIL/AMITRAZ/(S)-METHOPRENE AND THE COMBINATION OF IMIDACLOPRID/PERMETHRIN aGainst DERMACENTOR RETICULATUS, the EUROPEAN DOG TICK
}

\author{
FOURIE J.J.*, BEUGNET F.**, OLLAGNIER C.*** \& POLLMEIER M.G.**
}

\section{Summary:}

The sustained speed of kill against Dermacentor reticulatus of two topical combinations, one containing fipronil/amitraz/(S)-methoprene and the other, imidacloprid/permethrin, was evaluated in dogs. Two treated groups and one untreated control group of eight adult Beagle dogs each were randomly formed based on pre-infestation rates and bodyweight. Each treatment was administered topically once on Day 0 , according to the recommended label dose and instructions for use. All dogs were infested with 50 adult unfed $D$. reticulatus starting on Day 1 , then weekly, for a total of five weeks. While most studies determine tick efficacy at 48 hours (h), in this study, all remaining ticks were counted and categorized $24 \mathrm{~h}$ following each infestation. The numbers of ticks (living or dead) that remained attached on treated dogs were compared to those on the control animals. The percent reduction of attached ticks (disruption of attachment) at $24 \mathrm{~h}$ on dogs treated with fipronil/amitraz/(S)methoprene remained above $92 \%$ for four weeks. The reduction of attached ticks at $24 \mathrm{~h}$ on dogs treated with imidacloprid/permethrin did not reach $80 \%$ during the entire study. The number of ticks attached at $24 \mathrm{~h}$ was significantly $(\mathrm{p}<0.05)$ lower in the fipronil/ amitraz/(S)-methoprene group than in the imidacloprid/permethrin group in assessments on Days 2, 15, 22, 29 and 36. When assessing efficacy based upon live ticks on treated versus control dogs, fipronil/amitraz/(S)-methoprene $24 \mathrm{~h}$ efficacy was above $95 \%$ for four weeks, decreasing to $77.8 \%$ at Day 36 . The $24 \mathrm{~h}$ efficacy of imidacloprid/permethrin ranged from $56.2 \%$ to $86.7 \%$ through Day 29, never achieving $90 \%$ throughout the study. The 24-hour efficacy of fipronil/amitraz/(S)-methoprene was significantly $(p<0.05)$ higher than imidacloprid/permethrin at all time points, including Day 36.

KEY WORDS: Dermacentor reticulates, fipronil/amitraz/(S)-methoprene, imidacloprid/permethrin, ADVANTIX ${ }^{\circledR}$, CERTIFECT $^{\circledR}$.

\footnotetext{
* ClinVet, P.O. Box 11186, Universitas, Bloemfontein, 9321, Republic of South Africa.

** Merial S.A.S., 29, avenue Tony Garnier, 69007 Lyon, France.

**** Merial S.A.S., PIPA, CRSV, 1, allée des Cyprès, 01150 Saint-Vulbas, France.

Correspondence: Frédéric Beugnet.

E-mail: frederic.beugnet@merial.com
}

Résumé : ÉTUDE DE LA RÉMANENCE ET DE LA RAPIDITÉ D'ACTION DE DEUX COMBINAISONS ANTIPARASITAIRES EXTERNES, FIPRONIL/AMITRAZ/(S)MÉTHOPRĖNE ET IMIDACLOPRIDE/PERMÉTHRINE, SUR DERMACENTOR RETICULATUS, LA TIQUE EUROPÉENNE DU CHIEN

La rémanence et la rapidité d'action de deux antiparasitaires externes destinés au chien, I'un contenant fipronil/amitraz/(S)méthoprène et l'autre imidaclopride/perméthrine, ont été évaluées. Deux groupes traités et un groupe témoin de chacun huit chiens de race Beagle ont été constitués après une infestation préalable par des tiques. Chaque traitement topique en pipette est appliqué au jour 0 , selon les recommandations et instructions d'utilisation des laboratoires fabriquant. Tous les chiens sont infectés par 50 D. reticulatus adultes au jour 1, puis chaque semaine pendant cinq semaines. Alors que la plupart des études regardent l'efficacité anti-tiques à 48 heures (h), dans cette étude, les tiques restant sur les chiens ont été comptées et classées selon leur état (fixées ou non fixées, vivantes ou mortes, gorgées ou non gorgées) après $24 \mathrm{~h}$ de contact. Le nombre de tiques (vivantes ou mortes) qui restaient attachées sur les chiens traités a été comparé avec celui dénombré sur les chiens témoins non traités. Le pourcentage de réduction d'attachement (ou de perturbation d'attachement) à $24 \mathrm{~h}$ chez les chiens traités par la combinaison fipronil/amitraz/(S)méthoprène est resté supérieur à $92 \%$ pendant quatre semaines. La réduction d'attachement des tiques à $24 \mathrm{~h}$ chez les chiens traités par l'association imidaclopride/perméthrine n'a pas dépassé $80 \%$ durant cet essai. Le nombre de tiques fixées sur les chiens à $24 \mathrm{~h}$ était significativement plus faible $(p<0.05)$ dans le groupe traité fipronil/amitraz/(S)-méthoprène que dans le groupe imidaclopride/ perméthrine aux jours 2, 15, 22, 29 et 36. Si l'on étudie l'efficacité acaricide par comparaison au nombre de tiques vivantes sur les chiens témoins, cette efficacité à 24 h est restée supérieure à $95 \%$ pendant quatre semaines, puis a diminué à $77,8 \%$ au jour 36 dans le groupe fipronil/amitraz/(S)-méthoprène. L'efficacité acaricide à $24 \mathrm{~h}$ dans le groupe traité imidaclopride/perméthrine a été comprise entre 56,2 et $86,7 \%$ jusqu'au jour 29, ne dépassant jamais $90 \%$. L'efficacité acaricide à $24 \mathrm{~h}$ du groupe traité par l'association fipronil/amitraz/(S)-méthoprène a été significativement plus forte que dans le groupe imidaclopride/perméthrine à tous les points de comptage, jusqu'au jour 36.

MOTS-CLÉS : Dermacentor reticulatus, fipronil/amitraz/(S)-méthoprène, imidaclopride/perméthrine, ADVANTIX ${ }^{\circledR}$, CERTIFECT $^{\circledR}$.

T licks and fleas are the primary ectoparasites infesting dogs (Pfister, 2011). Dermacentor tick species are present worldwide and can be vectors of disease for humans and animals (Berrada et al., 2009; Nicholson et al., 2010). In Western Europe, Dermacentor reticulatus is a common tick species affecting dogs and is the primary vector of Babesia 
canis canis (Beugnet \& Marie, 2009). Effective control of tick infestations on dogs is based on several strategies, including avoidance of infested environments, environmental controls, and regular application of acaricides to the dog. Environmental control measures are often complex and have varying success rates. Tick infested environments are not easily identifiable; therefore avoidance is not always possible. Thus, regular topical applications of acaricides or combination products (e.g. insecticide/acaricide) are often used to control external parasite infestations in domestic animals (Brianti et al., 2010). Spot-on formulations of insecticides and/or acaricidal drugs provide a convenient method for external parasite control in dogs and cats. In this study, two topical insecticide/acaricide combination products with labelled activity against ticks were chosen for comparison: the new topical combination fipronil/amitraz/(S)-methoprene in a dual chamber pipette (fipronil $10 \% \mathrm{w} / \mathrm{v}$ and (S)-methoprene $9 \%$ $\mathrm{w} / \mathrm{v}$ in chamber one and amitraz $20 \% \mathrm{w} / \mathrm{v}$ in chamber two; CERTIFECT ${ }^{\circledR}$ Spot-On Dog [registered trademark of Merial. All other marks are the property of their respective owners]) and imidacloprid/permethrin in a single chamber pipette (imidacloprid $10 \% \mathrm{w} / \mathrm{v}+$ permethrin $50 \% \mathrm{w} / \mathrm{v}$; ADVANTIX ${ }^{\circledR}$ [Europe; Bayer AG] or K9 ADVANTIX ${ }^{\circledR}$ [United States; Bayer Animal Health]).

As a single entity, fipronil provides broad spectrum of activity against insects (including fleas and lice) and acari (including ticks and other mites). The new combination with amitraz was formulated and developed to significantly increase the speed of kill of fipronil on ticks, due to a potentiation effect provided by amitraz (Pfister et al., 2011; Prullage et al., 2011). This new spot-on combination has been registered in 2011 in both the USA and Europe. Imidacloprid is an insecticide with no labelled activity against acari; thus, a combination product including permethrin was developed to create a product with a broadened range of efficacy. It is commercialized in the USA and in European countries since a few years.

Tick efficacy guidelines for approval in both EU and USA typically require efficacy $\geq 90 \%$ at 48 -hour counts (Marchiondo et al., 2007). The purpose of the study was to assess the ability of each product to disrupt attachment of ticks and to assess the sustained speed of kill activity at 24-hour counts. Both rapid kill and disruption of attachment of newly acquired ticks would lower the numbers of engorged ticks seen, and potentially reduce the risk of transmission of many tick-borne pathogens. While rapid activity is desirable, it is equally important that rapid activity is sustained throughout the treatment interval. This study assessed the 24-hour activity against weekly infestations of D. reticulatus ticks, through Day 36.
MATERIALS AND METHODS

\section{STUDY DESIGN}

T This study was a randomized, blinded, negative controlled comparative-efficacy study. All dogs were managed similarly and with due regard for their well-being. All were handled in compliance with local and Merial Institutional Animal Care and Use Committee approvals and in accordance with any applicable laws and regulations. Each dog was individually housed throughout the study.

From a pool of 28 healthy dogs, 24 dogs demonstrating the highest tick counts following a prequalification infestation were selected for use in this study. Dogs were allocated to one of eight replicates of three dogs each based on pre-treatment bodyweight, then the dogs within each replicate were randomly allocated to one of three groups of eight dogs each. Dogs used in this study hadn't been treated with any ectoparasiticides in the preceding three months. Dogs were shampooed seven days prior to treatment with a non-insecticidal shampoo $\left(\operatorname{Purl}^{\circledR}\right.$ Shampoo, registered trademark of Kryon laboratories, South Africa).

Treatments were applied by weight, in accordance with approved-label directions on Day 0. The dogs were weighed to determine appropriate dosing. If the weight of any dog did not fall exactly on a whole pound, their weight was rounded up to the next whole pound. Dogs weighed between 27 and 53 lbs (12.2 to $24 \mathrm{~kg}$ ).

Dogs in Treatment Group 1 remained untreated.

Dogs in Treatment Group 2 (Table I) were treated with the appropriate size of CERTIFECT ${ }^{\circledR}$ Spot-On for dogs (in total volume applied on dogs: fipronil $6.26 \% \mathrm{w} / \mathrm{v}$, amitraz $7.48 \% \mathrm{w} / \mathrm{v}$ and (S)-methoprene $5.63 \% \mathrm{w} / \mathrm{v}$ ). The total volume was applied on the dog's midline; half midway up the neck, half between the shoulder blades.

Dogs in Treatment Group 3 (Table I) were treated with the appropriate size pipette of ADVANTIX ${ }^{\circledR}$ spot-on for dogs (imidacloprid $10 \% \mathrm{w} / \mathrm{v}+$ permethrin $50 \%$ $\mathrm{w} / \mathrm{v})$. For treatment administration, the total volume was applied according to package instructions by parting the hair and applying directly on the skin in three spots along the midline from the top back of the shoulder blades to the base of the tail.

The $D$. reticulatus ticks used in this study were a laboratory strain, obtained from the ClinVet colony, free from known tick-borne pathogens and from a strain with no known resistance to any ectoparasiticide.

Dogs were infested with $50 \mathrm{D}$. reticulatus (50:50 sex ratio), for pre-treatment (Day -3) and for each subsequent infestation (Days 1, 7, 14, 21, 28 and 35). Each dog was sedated, and the ticks were gently deposited 


\begin{tabular}{cccc}
\hline Treatment & Bodyweight range - lbs (kg) & Pipette size & Pipette volumes - mL \\
\hline Certifect $^{\circledR}$ Spot-On for dogs & $23-44(10-20)$ & M & 2.14 \\
& $45-88(20-40)$ & $\mathrm{L}$ & 4.28 \\
\hline Advantix $^{\circledR}$ spot-on for dogs & $21-55(10-25)$ & $\mathrm{Red} / 55$ & 2.5 \\
\hline
\end{tabular}

Table I. - Dosage of dogs in the treated groups.

\begin{tabular}{lcccc}
\hline Category & General findings & Attachment status & $\begin{array}{c}\text { Interpretation for prevention } \\
\text { of attachment }\end{array}$ & $\begin{array}{c}\text { Interpretation for killing effect } \\
\text { (acaricidal) }\end{array}$ \\
\hline 1 & Live & Free & Demonstrated & Not demonstrated \\
2 & Live & Attached; unengorged & Not demonstrated & Not demonstrated \\
3 & Live & Attached; engorged & Not demonstrated & Not demonstrated \\
4 & Dead & Free & Demonstrated & Demonstrated \\
5 & Dead & Attached; unengorged & Not demonstrated & Demonstrated \\
6 & Dead & Attached; engorged & Not demonstrated & Nomonstrated \\
\hline
\end{tabular}

Adapted from Marchiondo et al., 2007.

${ }^{1}$ Engorged tick: a tick with a conspicuous enlargement of the alloscutum that has blood in its digestive tract, as shown by squeezing/ crushing of the tick on white paper.

Table II. - Categorization of ticks for counting and interpretation.

on the lateral aspect of the dog's chest. Any remaining ticks were counted 24 hours after each infestation.

All personnel involved with evaluation of efficacy were unaware of treatment status of dogs in the study. Personnel with access to the treatment assignments were identified prior to the first treatment being administered, and blinding was maintained throughout the study.

\section{SPECIFICATION OF STUDY VARIABLES}

The ticks were categorized according to Table II. Categorization of the ticks allow calculation of the percent efficacy (killing effect), as well as the calculation of the attachment rate, in comparison with the untreated control group.

\section{DATA ANALYSIS}

To measure disruption of attachment rates, total counts of ticks in categories 2, 3, 5, and 6 (Table II), i.e. all "attached" categories (live or dead), were transformed to the natural logarithm of (count +1$)$ for calculation of geometric means by treatment group at each time point.

To measure the killing effect (\% acaricidal efficacy), the total counts of adult ticks in categories 1 through 3 and 6 were transformed to the natural logarithm of (count +1$)$ for calculation of geometric means by treatment group at each time point. The ticks in the three "Live" categories, as well as in the "Dead, attached, engorged" category, were interpreted as treatment failures. Their counts were combined and the total for each dog was used in the subsequent analysis.
For both analysis, percent reduction from the negative control group (Treatment Group 1) mean was calculated for Treatment Groups 2 and 3, if applicable, at every post-treatment time point using the formula $[(\mathrm{C}-\mathrm{T}) / \mathrm{C}] \times 100$, where $\mathrm{C}$ is the geometric mean for the negative control group and $\mathrm{T}$ is the geometric mean for Treatment Group 2 or 3. Treatment Group 2 was compared to each of the other treatment groups (Treatment Groups 1 and 3) using Analysis of Variance on log count. All testing was two-sided at the significance level $\alpha=0.05$.

\section{RESULTS}

\section{DISRUPTION OF ATTACHMENT}

The disruption of attachment is based on the counts of all attached ticks, live or dead, that are present at assessment, which in this study occurred at the 24-hour count (Table III, Fig. 1) (Prullage et al., 2011). The percentage of attachment at 24 hours was significantly higher $(\mathrm{p}<0.05)$ in the control group than in the treated groups at all time points. The rate of attachment was significantly lower $(p<0.05)$ in the CERTIFECT $^{\circledR}$-treated group than the ADVANTIX ${ }^{\circledR}$-treated group throughout the entire study. In the CERTIFECT ${ }^{\circledR}$ treated group, $92.3 \%$ to $98.5 \%$ of ticks were prevented from attachment compared to the untreated group until Day 29. In the ADVANTIX ${ }^{\circledR}$-treated group $54.7 \%$ to $78.4 \%$ of ticks were prevented from attachment compared to the untreated group until Day 29 (Table III). 


\begin{tabular}{|c|c|c|c|c|c|c|c|c|c|c|}
\hline \multirow[b]{3}{*}{ Day } & \multicolumn{5}{|c|}{ Categories 2, 3, 5 and 6} & \multicolumn{5}{|c|}{ Categories 1, 2, 3 and 6} \\
\hline & \multirow{2}{*}{$\begin{array}{c}\text { Control } \\
\text { Cnt. }^{1}\end{array}$} & \multicolumn{2}{|c|}{ Certifect $^{\circledR}$} & \multicolumn{2}{|c|}{ Advantix $^{\circledR}$} & \multirow{2}{*}{$\begin{array}{c}\text { Control } \\
\text { Cnt. } \\
\end{array}$} & \multicolumn{2}{|c|}{ Certifect $^{\circledR}$} & \multicolumn{2}{|c|}{ Advantix ${ }^{\circledR}$} \\
\hline & & Cnt. & $\%^{2}$ & Cnt. & $\%$ & & Cnt. & $\%$ & Cnt. & $\%$ \\
\hline 2 & 23.46 & 1.28 & 94.6 & 8.26 & $64.8^{*}$ & 23.03 & 0.19 & 99.2 & 6.50 & $71.8^{*}$ \\
\hline 8 & 24.75 & 1.21 & 95.1 & 5.34 & 78.4 & 23.42 & 0.00 & 100.0 & 3.11 & $86.7^{*}$ \\
\hline 15 & 30.60 & 0.45 & 98.5 & 9.96 & $67.5^{*}$ & 30.49 & 0.22 & 99.3 & 8.93 & $70.7^{*}$ \\
\hline 22 & 33.43 & 2.58 & 92.3 & 11.30 & $66.2^{*}$ & 33.18 & 1.59 & 95.2 & 8.90 & $73.2^{*}$ \\
\hline 29 & 33.56 & 2.02 & 94.0 & 15.19 & $54.7^{*}$ & 33.43 & 1.65 & 95.1 & 14.63 & $56.2^{*}$ \\
\hline 36 & 29.37 & 6.30 & 78.6 & 20.92 & $29.3^{*}$ & 29.46 & 6.55 & 77.8 & 21.56 & $27.3^{*}$ \\
\hline
\end{tabular}

${ }^{1} \mathrm{Cnt}$. = geometric mean tick count.

$2 \%=$ percent disruption of attachment at 24 hours for categories 2, 3, 5 and 6 or percent killing efficacy at 24-hour counts for categories $1,2,3$ and 6 .

* Significant difference between the two treatment groups at $\mathrm{p}<0.05$.

Table III. - Geometric means of Dermacentor reticulatus ticks counts by category at 24-hour post-infestation and percent of disruption of attachment and percent killing efficacy at 24-hour counts.

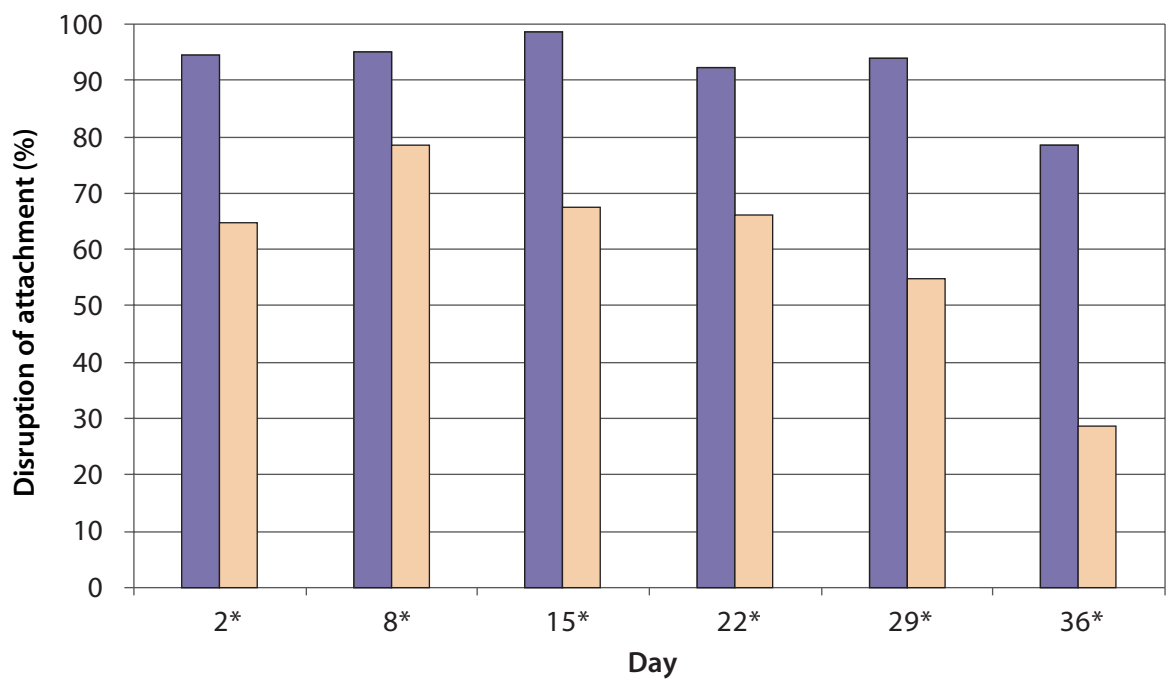

Fig 1. - Disruption of attachment of Dermacentor reticulatus at 24-hour post-infestation.

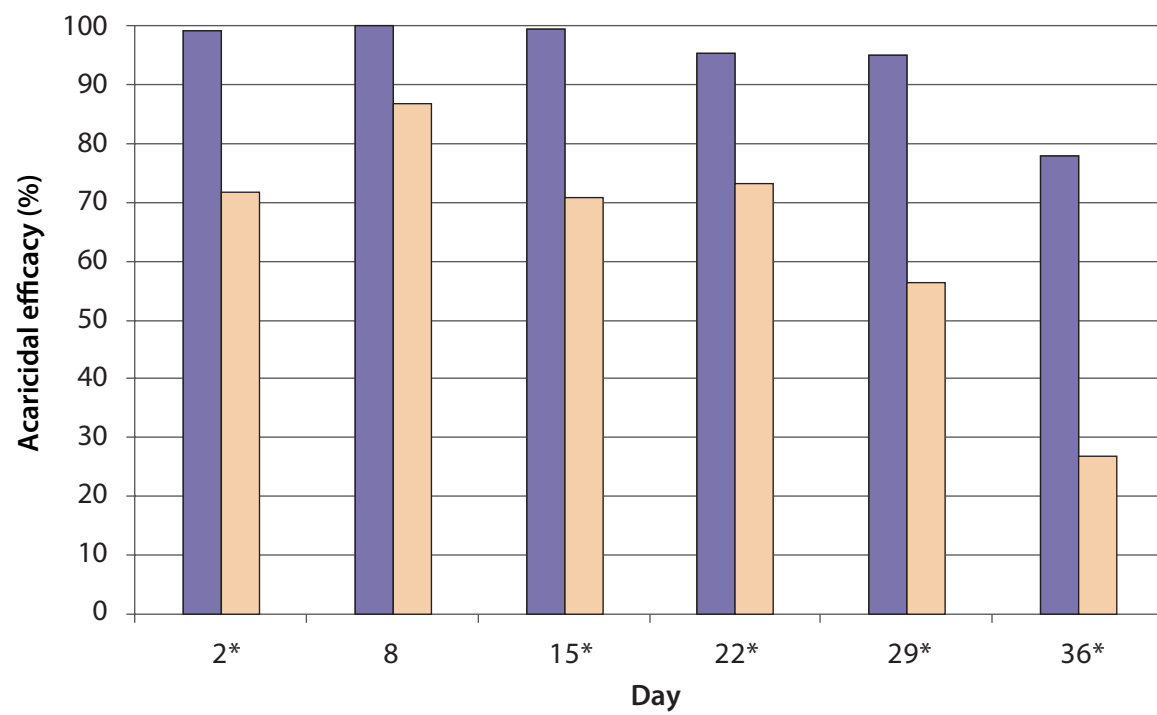

Certifect $^{\oplus}$

Advantix $^{\circledast}$

* Significant difference

between the two groups at $p<0.05$
Certifect $^{\oplus}$

Advantix $^{\circledast}$

* Significant difference

between the two groups at $p<0.05$

Fig 2. - Comparative acaricidal efficacy at 24-hour tick counts. 


\section{SPEED OF KILL}

The killing efficacy is shown on Table III and Fig. 2. The fipronil/amitraz/(S)-methoprene efficacy at 24hour counts was above $95 \%$ through the four weeks following treatment, decreasing to $77.8 \%$ following the Day 35 challenge. The imidacloprid/permethrin 24 hours efficacy did not reach $90 \%$ efficacy at any assessment throughout the study, with killing efficacy through the four weeks ranging from $56.2 \%$ to $86.7 \%$ at 24-hour counts. The difference between the two treatment groups was significant at all time points including Day 36.

\section{DISCUSSION}

The tick counts in this study were conducted at 24 hours following each challenge, rather than 48 hours assessments. Previous studies have demonstrated that the efficacy of the imidacloprid/ permethrin combination at 48 hours is typically above $90 \%$ for three to four weeks or more, dependant upon the tick species studied (Doyle et al., 2005; Dryden et al., 2008; Tielemans et al., 2010). Another study performed against two tick species reported a rapid, but short-term activity of imidacloprid/permethrin causing a significant number of one of the tick species to remain unattached and repelled following infestation (Dryden et al., 2006). The quicker a product acts, the lower the probability that a tick will initiate its blood feeding and transmit pathogens. Short-term rapid activity is important, but pets can be exposed to ticks throughout the treatment interval, not just in the days immediately following treatment. Therefore, the duration of that rapid activity is key. By 24 hours after each infestation the fipronil/amitraz/(S)-methoprene combination showed disruption of attachment $>90 \%$ for a full month and efficacy $>95 \%$ against $D$. reticulatus for a full month, demonstrating both a rapid and most importantly a consistent performance throughout the treatment period. Such consistency would be important for pet owners, who do not want to see engorged ticks on their dogs. Moreover, it is expected that the disruption of attachment and efficacy provided by 24 hours would reduce the risk of transmission of many pathogens transmitted by ticks.

\section{REFERENCES}

Berrada Z.L. \& Telford III S.R. Burden of tick-borne infections on American companion animals. Topics in Companion Animal Medicine, 2009, 24, 175-181.

Beugnet F. \& Marie JL. Emerging arthropod borne diseases of companion animals in Europe. Veterinary Parasitology, 2009, 163, 298-305.

Brianti E., Pennisi M.G., Brucato G., Risitano A.L., Gaglio G., Lombardo G., Malara D., Fogliazza A. \& Giannetto S. Efficacy of the fipronil $10 \%+(\mathrm{S})$-methoprene $9 \%$ combination against Rhipicephalus sanguineus in naturally infested dogs: speed of kill, persistant efficacy on immature and adult stages and effect of water. Veterinary Parasitology, 2010, 170, 96-103.

Doyle V., Beugnet F. \& Carithers D. Comparative efficacy of the combination fipronil-(S)-methoprene and the combination permethrin-imidacloprid against Dermacentor reticulatus, the European dog tick, applied topically to dogs. Veterinary Therapeutics, 2005, 6 (4), 303-310.

Dryden M.W., Payne P.A., Smith V. \& Hostetler J. Evaluation of an imidacloprid $(8.8 \% \mathrm{w} / \mathrm{w})$-permethrin $(44 \% \mathrm{w} / \mathrm{w})$ topical spot-on and a fipronil $(9.8 \% \mathrm{w} / \mathrm{w})-(\mathrm{S})$-methoprene $(8.8 \% \mathrm{w} / \mathrm{w})$ topical spot on to repel, prevent attachment, and kill adult Rhipicephalus sanguineus and Dermacentor variabilis ticks on dogs. Veterinary Therapeutics, 2006, 7, 187-198.

Dryden M.W., Payne P.A., McBride A., Mailen S., Smith V. \& CARITHERS D. Efficcay of fipronil $(9.8 \% \mathrm{w} / \mathrm{w})+(\mathrm{S})-$ methoprene $(8.8 \% \mathrm{w} / \mathrm{w})$ and imidacloprid $(8.8 \% \mathrm{w} / \mathrm{w})$ + permethrin $(44 \% \mathrm{w} / \mathrm{w})$ against Dermacentor variabilis (American dog tick) on dogs. Veterinary Therapeutics, 2008, 9 (1), 15-25.

Marchiondo A.A., Holdsworth P.A., Green P., Blagburn B.L. \& JACOBS D.E. World Association for the Advancement of Veterinary Parasitology (WAVVP) guidelines for evaluating the efficacy of parasiticides for the treatment, prevention and control of flea and tick infestation on dogs and cats. Veterinary Parasitology, 2007, 145, 332-344.

Nicholson W.L., Allen K.E., McQuiston J.H., BreitschwerdT E.B. \& LiTTLE S.E. The increasing recognition of rickettsial pathogens in dogs and people. Trends in Parasitology, 2010, 26, 205-212.

PFISTER K. Fipronil, amitraz and (S)-methoprene - a novel ectoparasiticide combination for dogs. Veterinary Special Edition, 2011, 179 (4), 291-353.

Prullage J., Hair J., Everett W., Yoon S.Y., Cramer L., Franke S., Cornelison M. \& Hunter J. The prevention of attachment and the detachment effects of a novel combination of fipronil, amitraz and (S)-methoprene for Rhipicephalus sanguineus and Dermacentor variabilis on dogs. Veterinary Special Edition, 2011, 179 (4), 302-310.

Prullage J.B., Cawthorne W.G., Le Hir de Fallois L.P. \& Timmons P.R. Synergy between fipronil and amitraz in a Rhipicephalus sanguineus tick residual contact test. Experimental \& Applied Acarology, 2011, 54, 173-176.

Tielemans E., Manavella C., Pollmeier M., Chester T., Murphy M. \& Gale B. Comparative acaricidal efficacy of the topically applied combinations fipronil/(S)-methoprene, permethrin/imidacloprid and metaflumizone/amitraz against Dermacentor reticulatus, the Eurpean dog tick (Ornate dog tick, Fabricius, 1794) in dogs. Parasite, 2010, 17, 343-348.

Received on July $1^{\text {st }}$, 2011 Accepted on July $13^{\text {th }}, 2011$ 